\title{
A corporação que mudou o mundo: como a Companhia das Índias 0rientais moldou a multinacional moderna ${ }^{1}$
}

\author{
The corporation that changed the world: how the East India Company \\ shaped the modern multinational \\ La corporación que cambió el mundo: como la Compañía de las Indias \\ Orientales moldó la multinacional moderna
}

Emannuel Reichert

Nick Robins seguiu uma opção de carreira pouco comum entre historiadores: entrou para o meio empresarial, envolvendo-se com questões relacionadas à responsabilidade social das corporações e atualmente está dirigindo o Centro de Mudanças Climáticas do HSBC. Esse currículo inusitado deixou-o especialmente preparado, talvez, para a temática deste livro: a história da primeira grande multinacional que foi, ao mesmo tempo, um capítulo importante na construção do imperialismo britânico.

Sem declará-lo explicitamente, a obra parece estar afiliada à corrente historiográfica da "nova história imperial" inglesa, voltada para a influência recíproca entre metrópole e colônias e destas umas com as outras. Segundo Tony Ballantyne, um dos expoentes dessa linha de pesquisas, o império asse- melha-se a uma complexa teia por onde circulam capital, pessoas e ideias e na qual um lugar pode ocupar várias posições - o centro administrativo de uma colônia exercia a função de "centro subimperial", subordinado à metrópole, mas dominante em relação ao restante da colônia e, por vezes, também em relação a outras colônias ${ }^{2}$. Robins mostra a Companhia das Índias Orientais como um fio crucial na teia imperial, capaz de exercer um impacto dramático na Inglaterra, Índia, Estados Unidos e China.

\footnotetext{
Mestre em História pela Universidade de Passo Fundo.

Recebido em 25/04/2013 - Aprovado em 25/06/2013 http://dx.doi.org/10.5335/hdtv.13n.2.3351
} 
A Companhia era institucionalmente parte antiga e parte moderna, um misto de guilda monopolista e sociedade por ações, fazendo "a ponte entre o conceito medieval de corporação como organização essencialmente pública e o modelo industrial de empresa que atua no exclusivo interesse de seus acionistas" ${ }^{3}$. Ela surgiu em 1600 por meio de uma Carta de Privilégios da rainha Elizabeth que concedia o monopólio periodicamente renovável do comércio com as Índias Orientais a um grupo de 218 investidores, seus primeiros acionistas. Em suas primeiras décadas, fez concorrência com o estado da Índia português e a Companhia das Índias Orientais holandesa em torno das mercadorias da Índia e das Ilhas das Especiarias do Sudeste asiático, combinando comércio e pirataria.

No final de seu primeiro século de existência, a Companhia sofreu reveses graves na Índia e na Inglaterra. Em 1686, seu então presidente Josiah Child enviou tropas à Índia na esperança de obter concessões comerciais do imperador mogol Aurangzeb, senhor da maior parte da região, de cuja boa vontade dependia a existência do comércio com os ingleses. A guerra foi uma vitória total para Aurangzeb, que manteve os direitos comerciais da Companhia, mas exigiu uma reparação pesada pelos prejuízos sofridos. No plano interno, a empresa enfrentou a oposição do governo pós-Revolução Gloriosa, menos disposto que seus antecessores a conceder monopólios sobre o comércio exterior, e dos representantes da indústria têxtil, que exigiam medidas protecionistas a fim de competir com os tecidos indianos importados a baixo custo pela Companhia.
Empenhada em manter seus privilégios, a direção recorreu ao suborno de numerosos membros do governo, empréstimos sem juros para a Coroa e, finalmente, à fusão com uma nova companhia comercial criada com autorização do Parlamento para substituir a antiga.

Passada a crise e os escândalos, a Companhia prosseguiu com suas atividades comerciais, encontrando novos mercados para seus produtos: "com o mercado de escravos africanos em acelerada ascensão, os tecidos de algodão indianos vieram a se tornar um artigo básico de escambo por carregamentos humanos. Era a globalização ao estilo georgiano" $^{\prime 4}$. Na metade do século 18, novos problemas provocaram um aumento das tropas a serviço da Companhia na Índia. Os comerciantes franceses, com sua Compagnie Perpetuelle des Indes, faziam séria concorrência aos ingleses, e quando França e Inglaterra entravam em guerra suas respectivas corporações também se enfrentavam. Além disso, o governante de Bengala, Siraj-ud-Daula, mostrava-se cada vez mais insatisfeito com os ingleses, que fortificavam o porto de Calcutá (principal entreposto da Companhia) e abusavam de seus privilégios fiscais, vendendo licenças para mercadores locais realizarem negócios sob sua proteção, livres de impostos. Fracassadas as negociações, Siraj-ud-Daula tomou Calcutá e entrou em guerra com a Companhia. Ele foi derrotado na batalha de Plassey, em 1757, graças à traição de seu general Mir Jafar, a quem os ingleses ofereceram o trono.

Soberana de fato sobre uma população mais numerosa que a da Inglaterra, a Companhia desviou-se de sua função mercantil 
para assumir o controle de uma porção cada vez maior da Índia, em uma sequência de conquistas com efeitos desastrosos para os governados. Suas prioridades foram mostradas em 1769 e 1770, quando a seca destruiu metade das colheitas de Bengala. A resposta dos executivos ingleses foi comprar grandes estoques de grãos e sementes e vendê-los a preços altos; como resultado, os dividendos dos acionistas foram aumentados enquanto pelo menos 1,2 milhões de bengaleses morreram de fome.

A situação curiosa de uma empresa administradora de grandes territórios gerou temor em muitos ingleses, convictos de que "a Companhia se tornara um híbrido monstruoso, parte comerciante de Leadenhall Street, parte déspota oriental" ${ }^{\prime \prime}$. As acusações de má-gestão e corrupção, somadas ao medo de que a riqueza indiana pudesse comprar o governo inglês, levaram a uma série de leis que, ao final, mantinham a existência formal da corporação e os dividendos dos acionistas enquanto efetivamente estatizavam sua administração, permitindo ao Parlamento selecionar os ocupantes de seus principais cargos executivos.

As transformações causadas pela empresa não haviam acabado: ela desempenhou um papel na independência das 13 colônias americanas. Os colonos opunham-se aos impostos provindos de Londres, entre eles um que incidia sobre o chá. Em 1773, foi aprovada a Lei do Chá, permitindo à Companhia vender chá às colônias com impostos reduzidos, que possibilitavam um preço mais baixo que o do produto contrabandeado consumido pelos colonos: "o governo britânico esperava que os preços mais baixos levassem os americanos a aceitar a permanência do modesto imposto sobre o chá" ${ }^{\prime \prime}$. Ao invés disso, eles direcionaram seu rancor contra a Companhia, boicotando suas mercadorias e atirando ao mar a carga de três navios - a Festa do Chá de Boston, um dos eventos iniciais da independência.

O chá recusado pelos colonos vinha da China, pago com ópio que a Companhia obtinha das fazendas de Bengala. A proibição chinesa do ópio era ignorada mediante suborno às autoridades alfandegárias, e assim "o sólido superavit comercial chinês de cerca de 26 milhões de dólares entre 1800 e 1810 se transformou em deficit de 38 milhões de dólares entre 1828 e 1836"7. Quando o comissário imperial Lin Tse-hsu começou a fazer cumprir as leis chinesas, confiscando e destruindo cargas de drogas em 1839, foi o pretexto necessário para o governo britânico entrar em guerra com a China: a primeira Guerra do Ópio, início de uma série de humilhações que reduziriam o Império do Meio a uma condição quase colonial até a Segunda Guerra Mundial.

A irrelevância da Companhia crescia desde 1813, quando perdeu seu tradicional monopólio do comércio oriental em um contexto de adesão inglesa ao liberalismo. Sua atividade mercantil declinou, reduzindo seu papel a um braço semiprivado do governo encarregado da administração da Índia. A gota da água foi a Grande Rebelião indiana de 1857, revolta contra a dominação inglesa iniciada, ironicamente, pelos sipaios, soldados nativos a serviço da corporação. Após o fim dos conflitos no ano seguinte, o Parlamento transferiu para si e para a rainha Vitória o governo indiano. A Companhia 
pouco mais fez desde então, exceto distribuir os dividendos pagos pelo governo até sua extinção em 1874.

Robins consultou uma considerável quantidade de fontes primárias, utilizando a documentação produzida pela corporação e os relatos de sua atividade feitos por simpatizantes e adversários. Baseado nesse material, o livro mostra eventos importantes da história mundial ainda pouco tratados pela literatura em português. Igualmente importante é sua descrição, mais atual do que nunca, dos abusos de que é capaz o capitalismo desregulado. A história da Companhia das Índias Orientais tem importância no presente: "uma confrontação honesta com as origens corporativas da Era Moderna pode tanto ajudar a iluminar nossa história quanto estimular novas ações para alinhar as corporações ao interesse público" ${ }^{\prime 8}$.

Por todos esses motivos, a obra é altamente recomendada.

\section{Notas}

1 ROBINS, Nick. A corporação que mudou o mundo: como a Companhia das Índias Orientais moldou a multinacional moderna. Rio de Janeiro: Bertrand Brasil, 2012.

2 BALLANTYNE, Tony. Orientalism and race: Aryanism in the British Empire. New York: Palgrave Macmillan, 2002, p. 15.

3 ROBINS, op. cit., p. 52.

4 Ibid., p. 95.

5 Ibid., p. 156.

6 Ibid., p. 166.

7 Ibid., p. 220.

8 Ibid., p. 269. 